\title{
Does God Care about the Oxen? Some Thoughts on the Protection of Animals in the Law Texts of the OT from a Canonical Perspective
}

\author{
HaNS-Georg WÜNCH (TheologischeS SEMinar RHEINLAND AND \\ University OF SOUTH Africa)
}

\begin{abstract}
In 1 Cor 9:9, Paul cites Deut 25:4 ("Do not muzzle an ox while it is treading out the grain") and asks, "Is it about oxen that God is concerned?" This question seems to be waiting for the definitive answer, "No, it is not." Is Paul really saying that God is not concerned about the oxen? This paper considers various passages in the OT (especially law texts) that appear to deal with the protection of animals. The thesis is that God is indeed concerned about animals. Since God is the creator of everything, he cares for his entire creation. The article discusses the OT texts from a canonical perspective, looking for the common ideas instead of discussing possible developments of thoughts. It understands the biblical law texts concerning creation as examples of an "order of creation" (R. Murray), which lies behind these laws.
\end{abstract}

KEYWORDS: Animal protection, Old Testament law, Biblical theology, Creation care

\section{A INTRODUCTION}

In 1 Cor 9:9, Paul asks a question that has inspired the title of this article: ${ }^{1}$

Because it is written in the Law of Moses: "Do not muzzle an ox while it is threshing." Does God care about the oxen, or does he not surely speak because of us? Yes, it was written because of us, in that the plower should plow in hope and (also) the thresher in hope of receiving a share.

* Submitted: 26/05/2020; peer-reviewed: 10/09/2020; accepted: 15/10/2020. Hans Wünch, "Does God Care about the Oxen? Some Thoughts on the Protection of Animals in the Law Texts of the OT from a Canonical Perspective," Old Testament Essays 33 no. 3 (2020): 538-555. DOI: https://doi.org/10.17159/2312-3621/2020/v33n3a10.

1 All Biblical texts in the article are the author's own translations from the Greek or Hebrew. 
Paul's question "Does God care about the oxen?" seems to demand a categorically negative answer, 'No, of course not!' Some translations in fact formulate it precisely in this way. Many commentators also agree with the rendering. Gräßer, for example, states unequivocally that the answer to the rhetorical question must be "uneingeschränkt: Nein! Gott kümmert sich nicht um die Ochsen." New Testament scholars often argue that Paul's understanding of Deut 25:4 allegorizes $^{3}$ the Old Testament text by applying it to the situation in the church, ${ }^{4}$ while others argue against this view. ${ }^{5}$ An allegorical interpretation does not seem to correspond to the general understanding of Old Testament texts in the Jewish exegesis of Paul's time. In his article on 1 Cor 9:9-11, Instone Brewer reports having studied about 100 examples of Jewish exegesis from the time before 70 $\mathrm{AD}$; but in not one of these cases does any of the rabbis employ allegory or even attempt to say anything that is not directly supported by the plain meaning of the text. $^{6}$

Jewish exegesis considers this law to be one of the laws distinguishing the people of Israel from all other nations, as Strack and Billerbeck ${ }^{7}$ show. Rabbinic exegesis interprets Deut 25:4 according to the principle of qal wahomer (from the easy to the difficult). ${ }^{8}$ Is it really conceivable therefore that Paul, trained by the great rabbi Gamaliel, would argue in a completely different way,

2 Erich Gräßer, ,Noch einmal: Kümmert sich Gott etwa um die Ochsen?" ZAW 97/34 (2006), 278.

3 The term "allegory" is understood and used in this article in its historical sense as "saying something but meaning something different." This does not include metaphorical language or the use of parables.

4 E.g. Wolfgang Schrage, Der erste Brief an die Korinther $(1$ Kor 6,12-11,16) (EKKNT VII/2; Zürich: Neukirchen-Vluyn, 1995), 299; Christian Wolff, Der erste Brief des Paulus an die Korinther (3. korr. Aufl. THKNT 7; Leipzig: Evangelische Verlagsanstalt, 2011),193; Dieter Zeller and Heinrich A. W. Meyer, Der erste Brief an die Korinther (KEK 5; Göttingen: Vandenhoeck \& Ruprecht, 2011), 305-306.

5 Cf. Anthony C. Thiselton, The First Epistle to the Corinthian: A Commentary on the Greek Text (NIGTC; Grand Rapids: Eerdmans, 2007), 686, who is also of the view that the term "allegorical" is not appropriate for describing Paul's use of the Old Testament.

6 Instone D. Brewer, "1 Corinthians 9.9-11: A Literal Interpretation of 'Do not Muzzle the Ox," NTS 38/4 (1992): 554.

7 Hermann L. Strack and Paul Billerbeck, Kommentar zum Neuen Testament aus Talmud und Midrasch (München: C. H. Beck, 1926), 382.

8 Strack and Billerbeck, Kommentar, 385; cf. Christian Wolff, Der erste Brief des Paulus an die Korinther (Zweiter Teil: Auslegung der Kapitel 8-16; THKNT VII/2; Berlin: Evangelische Verlagsanstalt, 1982), 24; Wolff, Der erste Brief des Paulus an die Korinther, 193; Craig S. Keener, Kommentar zum Umfeld des Neuen Testaments: Historische, kulturelle und archäologische Hintergründe (Neuhausen-Stuttgart: Hänssler, 1998), 270. 
or does Paul, as other exegetes claim, follow the principles of Jewish exegesis of Deut 25:4 strictly? Many refer to Philo, who wrote about this and other laws concerning animals in his De virtues 125-147. Two things are worthy of note regarding Philo.

The first is that this great Jewish exegete, who is well known for his allegorical way of understanding the Old Testament, does not allegorise Deut 25:4 and other texts on animal care, but instead takes them literally. This seems to speak against Paul doing so. The second point is even more interesting. Philo states that the laws concerning the care of animals are nothing less than an extension of God's "principles of humanity and compassion even to the race of irrational animals." If therefore Paul now - as already stated - looks for the principle behind the law in Deut 25:4 and applies it to human beings, he applies the same hermeneutical key to this text. Eckhard Schnabel supports that idea ${ }^{10}$ and shows it to be in harmony with the context of Deut 25:4, which focuses on the poor in the society of Israel,,$^{11}$ as well as with the context of 1 Cor 9 , where we find other examples from agriculture in vv. 7 and $11 .{ }^{12}$

I therefore follow Roy E. Ciampa and Brian S. Rosner in their commentary on the First Letter to the Corinthians thus:

Paul's statement need not (and should not) be taken as an absolute denial that the law was given for the sake of animals, but as a strong assertion that God is even more concerned about humans. ${ }^{13}$

We can therefore conclude at the end of this first step of the research that Paul does not speak against God caring about the oxen. Only when we take this text literally can we then also apply it to other situations in the church of today as Paul does in 1 Cor 9:9-10.

God does care about the oxen, because God is the creator of everything in heaven and on earth. He is not only the King of Israel in Old Testament times and the King of the church in New Testament times, but he is also the King of the universe. This can also be seen in the Old Testament laws concerning the protection and care for animals. These texts are discussed from a canonical per-

9 Philo, On the virtues (de virtues): Early Jewish Writings, 125, Online: http://www.earlyjewishwritings.com/text/philo/book31.html.

10 Eckhard J. Schnabel, Der erste Brief des Paulus an die Korinther (2., ber. und erg. Aufl.; Witten: Brockhaus, 2010), 486-487.

11 Schnabel, Der erste Brief des Paulus an die Korinther, 486.

12 Ibid., 487.

13 Roy E. Ciampa and Brian S. Rosner, The First Letter to the Corinthians (PNTC; Nottingham: Eerdmans, 2010), 405. 
spective, looking for the common ideas instead of discussing possible developments of thoughts. The question, therefore, is whether and how these texts present a common attitude of God towards the animals.

\section{B GOD COMMANDS PROTECTION OF AND CARE FOR ANI- MALS}

The Old Testament law texts frequently mention animals. These references often occur quite unexpectedly in laws concerning the Israelites and their relation to God or their fellow Israelites. There seems to be no discernible reason for turning to the animal world, which suggests that these laws on animal care are not something "special"; they are just another way in which the relationship to God should reveal itself in the everyday life of the people of God.

Commentators differ widely in their explanation of some of these laws since the text itself usually does not give a reason for its stipulations. Should we understand them as laws showing humane behaviour? Are they laws about animal protection? Do they display a compassionate attitude towards the animal world? What makes this more difficult is that commentators in the Western world in particular very often have lost any direct contact with the animal world. They do not rely on animals directly for their daily food; they do not care for them personally (with the possible exception of pets). Lastly, when it comes to certain special regulations (for example the prohibition on boiling a young goat in its mother's milk), we simply do not have enough knowledge of the cultural and religious background of that time to definitively answer the question of why we find this law in the Old Testament at all.

It is therefore important to ask how we could understand the laws concerning animals principally if read from a canonical perspective. In this regard, the book The Cosmic Covenant by Robert Murray can be especially helpful. Murray is of the view "that the Bible contains a complex of themes relating to creation and order," and suggests that this has not received sufficient attention. ${ }^{14}$ Without going into the details of his idea of a "cosmic covenant," I consider this concept of "creation and order" to be very helpful. Many laws concerning the relationship between humans and animals can be understood in a dual way: (1) as implementations of a God-given order and (2) as exemplifications of compassionate behaviour towards God's creation. I therefore follow Murray, who states that:

It will be argued here (a) that com-passion, or proper feeling for fellow-creatures, is indeed fundamental and is seen as a religious duty, but also (b) that many of the laws are to be understood as determined

\footnotetext{
14 Robert Murray, The Cosmic Covenant: Biblical Themes of Justice, Peace and the Integrity of Creation (London: Sheed \& Ward, 1992), xviii.
} 
by a concept or order as 'holiness', which requires distinctions to be maintained as a proper way of reverencing the Creator in all his creatures. $^{15}$

It is difficult to find any classifications for the laws concerning animals in the Old Testament. I will therefore start with laws directly governing the killing of animals, either as sacrifice or for use as food. We will end with the more general laws concerning the protection of animals. In discussing the various laws, we will see how they fit into the concept of compassion and order as defined by Murray.

We will start with a law found in both Exod 22:29 and Lev 22:27:

You must do the same to your oxen (and) to your sheep: seven days it (the firstborn) shall be with its mother. At the eighth day, it shall be given to me (Exod 22:29).

An ox or a lamb or a goat - when it is born, it shall be seven days with its mother and at the eighth day and from then on, it will be accepted as a fire offering to Yahweh (Lev 22:27).

In Exodus, this law follows the law stating that the firstborn son of every couple belongs to the Lord (Exod 22:28). "The same" is true of the oxen and the sheep. The term שור, which is usually translated "oxen," is often used together with the describe all larger domestic animals (e.g. Gen 32:6; Exod 20:17; 21:33), while the term צאן denotes both sheep and goats. In Leviticus, the law is expressed more generally - only from the eighth day onward will any animal be acceptable as an offering. The Hebrew term translated as "acceptable" is רצה. The term means that something is pleasant or enjoyable. ${ }^{16}$ The verb, as well as the related noun רצון is very often found in texts related to worship. It denotes "that which is (or is not) pleasing to God."17

What is the reason for such a law? Keil and Delitzsch attribute the law to the fact that a young animal is self-sustaining only after its first week of life after its birth. They also make a connection between this one week and the week of creation. ${ }^{18}$ Walton et al. link this weeklong period to the circumcision of sons on the eighth day, ${ }^{19}$ in addition to viewing it in light of the "humane treatment of

15 Murray, Cosmic Covenant, 114.

16 Wilhelm Gesenius, Hebräisches und aramäisches Handwörterbuch über das Alte Testament (Heidelberg: Springer, 2013), 1264.

17 Terence E. Fretheim, "רצה" (NIDOTTE 5; ed. Willem A. van Gemeren; Carlisle: Paternoster, 1997), 1186.

18 Carl-Friedrich Keil and Franz Delitzsch, The Pentateuch (5th ed.; Commentary on the Old Testament/1; Grand Rapids: William B. Eerdmans, 1978), 436-437.

19 Cf. also Peter Enns, Exodus (NIVAC; Grand Rapids: Zondervan, 2000), 453. 
animals." ${ }^{20}$ In a similar vein, Roy Gane claims that the law was given "apparently out of respect for life." ${ }^{21}$ Duane Garrett puts forward a similar argument, stating that this "is healthier for the mother and also strengthens the calf or lamb, so that it is a better offering to YHWH and meal for the participants in the sacrifice." ${ }^{22}$ Hieke also explains that during the first five days after giving birth, the dam usually produces a particular kind of milk called colostrum, which is specially enriched with everything that the young animal needs, and that young dams in particular are more easily ready for milking afterwards if they are allowed to see their young for a certain time. ${ }^{23} \mathrm{He}$ goes on to argue that the understanding of this law as showing compassion for animals or even advocating some kind of animal protection is somehow "bemüht," because then the offering itself would have been questioned. For Hieke, this is "wohl eher Projektionen aus moderner Empfindsamkeit heraus. ${ }^{24}$

The above seems to be a very modern and humanistic approach to this law. Perhaps the problem lies not in understanding the law as requiring compassion for animals, but in the conclusions that are then assumed. Is abolishing offerings altogether the only way to show compassion or does such a requirement simply reflect a modern understanding of compassion? Nobuyoshi Kiuchi seems to point in the right direction when he writes that, "sacrificial animals have their own parental-filial relationship... A tender and considerate attitude towards the animals would be a natural and necessary attitude on the part of the offerer." ${ }^{25}$ I would therefore agree with John Durham, who argues that the eighth day is the first day on which "the animal could safely be taken from its mother." 26 This interpretation is in line with Philo, who describes the decision to take a new-born

20 John H. Walton, Victor Harold Matthews and Mark William Chavalas, The IVP Bible Background Commentary: Old Testament (6th ed.; Downers Grove: InterVarsity Press, 2004), 102.

21 Roy Gane, Leviticus, Numbers: From Biblical Text... to Contemporary life (NIVAC; Grand Rapids: Zondervan, 2004), 382.

22 Duane Garrett, A Commentary on Exodus (KEL; Grand Rapids: Kregel Academics, 2014), 522; cf. also Erhard S. Gerstenberger and Otto Kaiser, Das dritte Buch Mose: Leviticus (ATD 6; Göttingen: Vandenhoeck \& Ruprecht, 1953), 503; Douglas K. Stuart, Exodus (NAC 2; Nashville: Broadman \& Holman Publishers, 2006), 522.

23 Thomas Hieke, Levitikus 2: Teilband 16-27 (HTK 3/2; Freiburg im Breisgau: Herder, 2014), 863.

24 Hieke, Levitikus, 864.

25 Nobuyoshi Kiuchi, Leviticus (AOTC 3; Downers Grove: InterVarsity Press, 2007), 410.

26 John I. Durham, Exodus (WBC 3; Texas: Word Books, 1987), 330; cf. Tremper Longman and David E. Garland, Genesis-Leviticus (rev. ed.; EBC 1; Grand Rapids: Zondervan, 2005), 499; Jacob Milgrom, Leviticus: A New Translation with Introduction and Commentary (AB 3A; London: Yale University Press, 2008), 1883. 
animal for cooking or for sacrifice (he speaks about the "pretence of sacrificing them") as "a cruel disposition." 27 He then goes on to ask:

And why in addition to the pains which the animal bears in parturition, should you also inflict other pains from external causes, by the immediate separation of the mother from her offspring? For it is inevitable that she will resist and be indignant when they are thus parted, by reason of the affection implanted by nature in every mother towards her offspring, and especially at the time of their birth; since at this time the breasts are full of milk-like springs, and then if through want of the child which is to suck them the flow of milk receives a check, they become hardened by being distended by the weight of the milk, and the women themselves are overwhelmed with pain. ${ }^{28}$

Philo then formulates a connection between this example from nature and the behaviour of parents, who should learn from it, saying, "And this is ordained principally for your sake, you noble persons, that if you have it not by nature, you may at least learn proper affection for your kindred by instruction..."29

The text of Lev 22:27 is followed by another law concerning animals in v. 28, "And an ox or a sheep, itself and its young you shall not slaughter on one day." According to Keil and Delitzsch, this law is linked to the prohibition of cooking a new-born in its mother's milk (Exod 23:19 and Deut 11:6-7). ${ }^{30}$ Walton et al. view it as a regulation that protects those who do not have many animals, since owing to cultic requirements they could otherwise be left without enough animals to make a living. ${ }^{31}$ This seems a bit farfetched since the law speaks only of the same day, and does not prevent one of the animals from being slaughtered the next day. ${ }^{32}$

Again, I would like to quote Philo, who writes:

for even if they are both to be sacrificed, still it must be at different times, for it is the greatest extravagance of barbarity to slay in one day the animal which has been born and her who is the cause of its birth. $^{33}$

27 Philo, De virt., 126.

28 Ibid., 128.

29 Ibid., 133.

30 Keil and Delitzsch, Pentateuch, 437.

31 Walton et al., IVP Bible Background Commentary, 137.

32 Alternatively, the term "day" could be understood more generally as "time," at another time.

33 Philo, De virt., 134. 
Philo seems to argue that it is inconceivable to bring together life and death in such a way. The mother and her young are a symbol of life and abundance. To slaughter them both in one day would be "the greatest extravagance of barbarity," as he calls it. It is the "respect for life," 34 which forbids such an action. $^{35}$

The commentary by Tremper Longman and David Garland also leans in this direction, as the scholars hold that the prohibition of slaughtering "a whole family of animals for sacrifice on the same day demonstrates the identification of the sacrificial animal with the Israelite offering it. The family was the basic unit of society." 36

The next law we will look at has led to a whole system of legislation in Jewish society. It is found three times in the Old Testament-twice in Exodus (23:19b and 34:26b) and once in Deuteronomy (14:21). In all three verses, the words are verbatim: "You shall not cook a young goat in the milk of its mother" (Exod 23:19b//34:26b//Deut 14:21).

Even though this law has led to such a widespread set of regulations in Jewish society, its original meaning is much debated. A good overview of some of the possible meanings of this law is presented by Walton et al., ${ }^{37}$ who explain that it may be (1) a reaction against Canaanite or other foreign religious practices ${ }^{38}(2)$ an admonition to treat animals humanely (since there may still be mother's milk in the stomach of the young animal) and (3) the mother's milk may contain blood, which would make the meat of the young animal unclean.

The explanation of this law as a reaction against some foreign religious practice is usually supported by a reference in the broken passage of a thirteenth century BC Ugaritic text, which speaks of cooking a kid in milk. ${ }^{39}$ Nevertheless, this text does not speak of the milk of the mother, and the reference does not really help us to understand this law. ${ }^{40}$

34 Gane, Leviticus, Numbers, 382.

35 It seems farfetched to understand this law as some kind of blending prohibition ("Vermischungstabu") demanding that in offering the young the "sphere of power" ("Kraftsphäre") of the older animal should not be touched, as Gerstenberger and Kaiser thinks (Gerstenberger and Kaiser, Leviticus, 303).

36 Longman and Garland, Genesis-Leviticus, 779.

37 Walton et al., IVP Bible Background Commentary, 103.

38 Martin Noth is of the view that this presumably refers to "ein in fremden Kulten üblicher Brauch." Martin Noth, Das zweite Buch Mose (Exodus) (Das Alte Testament Deutsch-Neubearbeitungen 5; Göttingen: Vandenhoek \& Ruprecht, 2011), 156.

39 Longman and Garland, Genesis-Leviticus, 504.

40 Longman and Garland, Genesis-Leviticus, 504. 
The idea that this law was based on the fact that the milk of the mother may contain blood would fit into the context of Exod 23 and 34, where the preceding verses speak about offerings. In Deut 14, the context contains a reference to the prohibition on eating the meat of any animal that dies by itself. In this case, the meat of the dead animal would also contain its blood, and therefore be unclean. However, if this was also the reason for the command not to cook a young goat in the milk of its mother, why does the law not speak of using the milk of an animal that has just given birth? The special link between the young goat and its own mother seems to lead in another direction.

Again, a look at Philo might help. In his discussion of this special law, he writes:

For he looked upon it as a very terrible thing for the nourishment of the living to be the seasoning and sauce of the dead animal, and when provident nature had, as it were, showered forth milk to support the living creature ... that the unbridled licentiousness of men should go to such a height that they should slay both the author of the existence of the other, and make use of it in order to consume the body of the other. $^{41}$

As with the other laws already discussed, the reason behind this special command seems to be the deep respect for God's creation; such an action would disturb the God-given relationship between mother and offspring. Calum Carmichael interprets this law (together with the two already mentioned laws) as being a reflection of the "concern to avoid a blurring of the two opposites, life and death." ${ }^{2}$ Murray therefore rightly concludes that the true reason behind these three laws relating to the mother and her young is that:

the forbidden actions offend against proper order by bringing death into shocking contact with the source of life in such a way as to desecrate the due 'pity' of relationships. To offend in these ways is to sin against compassion and therefore against nature, including the true good of human nature. ${ }^{43}$

This also helps to understand why in all three passages there is a connection to the offer of the "firstfruits of your land" (in Exod 23 and 34, in both cases directly before the law concerning cooking the young goat in the milk of its mother), respectively the giving of the tithe in Deut 14, following the law. Everything nature produces for human beings must be brought in relation to God,

41 Philo, De virt., 143.

42 Callum M. Carmichael, "On Separating Life and Death: An Explanation of Some Biblical Laws," HTR 69/1-2 (1976): 1; cf. also Longman and Garland, Genesis-Leviticus, 504.

43 Murray, Cosmic Covenant, 117. 
who himself provides it. This is seen in the offering of the firstfruits, the tithe and the way we are to treat the relation between mother and child in the animal world.

There is another law dealing with a mother and her young, which we read in Deut 22:6-7:

\begin{abstract}
If you come across the nest of a bird in front of you on the way in any tree or on the ground (with) young ones or eggs, the mother sitting on the young ones or on the eggs, you shall not take the mother together with her young ones. You shall surely send away the mother, but the young ones you may take for you, in order that you shall have a good and a long life.
\end{abstract}

As was the case with the commands to leave a new-born animal with its mother for seven days, not to slaughter a mother and her offspring on the same day and not to cook a young goat in the milk of its mother, this law asks for respect for the God-given relationship between parents and their young. This relationship must be kept sacred, as Keil and Delitzsch state. ${ }^{44}$ The law concerning birds therefore "extends the principle of humanitarian concern beyond that of domestic animals... to animal life in general." 45

However, there is another aspect to this law. Although the eggs and the young birds could well be taken for food, the mother should be left alive, as she would then be able to lay more eggs and raise more young. ${ }^{46}$ In the Hebrew text, this is pronounced very strongly with the use of a figura etymologica, "You shall definitely leave the mother to fly away." Peter Craigie argues that this "legislation thus has something in common with modern conservation laws." 47 One could rephrase it as, "If you need to take the life of an animal, ${ }^{48}$ make sure that you do not sever the chain of life altogether." Alternatively, in even broader terms, we could say, "In using natural resources, do not exploit nature so that it cannot restore itself again."

44 Keil and Delitzsch, Pentateuch, 410.

45 Duane L. Christensen, Deuteronomy 21:10-34:12 (WBC 6B; Nashville: Word Books, 2002), 497.

46 Tremper Longman and David E. Garland, Numbers - Ruth (rev. ed.; The Expositor's Bible Commentary 2; Grand Rapids: Zondervan, 2012), 674.

47 Peter Craigie, The Book of Deuteronomy (NIVCOT 5; Grand Rapids: Eerdmans, 1981), 289.

48 We should not understand this law from our modern (Western) perspective, where it would be cruel to take the young ones or the eggs of a bird and eat them. In the time and culture of the OT, birds were typically part of the diet. If one just left a nest without taking the eggs or the young ones, this could have well meant an empty stomach in the evening. 
Walton et al. write:

Aside from the apparent humanitarian concern for the welfare of the creatures involved here, conservation of nature is found in leaving the mature bird to breed again. One might compare this with the prohibition against cutting down fruit trees in Deuteronomy 20:19-20. In both instances, future sources of food are preserved while an alternative is suggested for immediate needs. ${ }^{49}$

This law has a special addendum, "in order that you shall have a good and a long life," which is repeated several times to emphasise the importance of a law. We find it together with the requirements to honour one's parents (e.g. Deut 5:16), to use just weights (e.g. Deut 25:15), in the present context and with regard to wholehearted obedience to God's law as such (e.g. Deut 4:40).$^{50}$ It therefore emphasizes four main areas of relationship; the relationship with God himself, with one's parents, with one's neighbours, and with nature as created by God.

Another instance of an animal care law is found in the verses directly preceding this. In Deut 22:1-4, we read:

${ }^{1}$ You shall not see the ox of your brother or his sheep going astray and hide yourself from them. You shall surely return it to your brother. ${ }^{2}$ And when your brother is not near to you and you do not know him, then you shall take it into the midst of your house and it shall be with you until your brother searches for it and then you shall bring it back to him. ${ }^{3}$ So you shall also do to his donkey and so you shall do with his garment, and so you shall do with every lost thing of your brother, which is lost from him and you find it. You shall not be able to distance yourself from them. ${ }^{4}$ You shall not see the donkey of your brother or his ox, fallen down on the road and hide yourself from them. You shall sure help (them) up together with him.

The primary focus of this law is to regulate the relationship between a person and his or her fellow Israelite (brother or sister). It is not primarily a law on animal protection (in v. 3, it also speaks of the garment or everything lost by the brother). However, this relationship between the two persons also leads to the concern for the welfare of animals. Otto links this with the prohibition on taking the mother bird together with her eggs or young; in both cases we read "auf dem Weg." It is therefore not only the neighbour who is covered by this law, but also the need of the animals.

49 Walton et al., IVP Bible Background Commentary, 194.

50 Longman and Garland, Numbers-Ruth, 674.

51 Eckart Otto, Deuteronomium 12-34. Erster Teilband: 12,1-23,15 (HTKAT 5/3; Freiburg: Herder, 2016), 1686. 
However, there seems to be yet another aspect to this law. If we look at the verses following this command, we read first about the prohibition of a woman wearing men's clothing and vice versa. Then follows the law about the bird's nest found along the way, which we have already discussed. Is there perhaps a common theme connecting these three rather different laws together? This common theme can indeed again be seen in the order of God's creation. The relationship between a human being, his or her neighbour and the animals in his or her care are aspects of this order. Another aspect is the creation of man and woman in their diversity. Lastly, honouring the order of creation also means that one should not use God's creation simply to fulfil one's desires, but instead act responsibly towards the creator out of respect for his creation.

There is a slightly different version of the law concerning the ox and the donkey belonging to one's neighbour in Exod 23:4-5. While the text in Exod 23 is more interested in the relationship between the two persons, here the animal itself is the primary focus:
${ }^{4}$ When you come upon the ox of your enemy or his donkey going astray, surely return it to him. ${ }^{5}$ When you see the donkey of one who hates you lying (broken) down under his burden, you shall stop from leaving him alone (or: you shall stop from leaving it to him alone), you shall surely release (leave) (it) together with him! (which ver- sion).

The text means that one should not leave the donkey collapsed under its load to the responsibility of its owner (one's enemy), but instead help him release the donkey from its burden. This is similar to Deut 22:4. ${ }^{52}$ While in Deut 22 the aspect of the relationship to a fellow Israelite is very strong, the situation is somewhat different here. Whereas one may see the challenge to love one's enemy in this law, the main direction is not the relationship with that person, but the necessary help for the animal in need. Not even the fact that the owner of the animal is an enemy should keep one from helping the owner.

The text in v.5 is not easy to translate. If you see the donkey of your enemy lying under his burden, "you shall refrain from leaving him alone," the Hebrew reads. The first question is to whom does the "him" refer - the donkey or the enemy? If it means the donkey, the idea is that one should not leave the donkey lying under his burden. If it relates to the enemy, it means that one should not leave the problem of the burdened donkey to one's enemy alone. Since the text continues by saying, "you shall surely release together with him," where the "him" clearly refers to the enemy, it seems that this is also true of the first sentence.

52 Cf. Keil and Delitzsch, Pentateuch, 144-145. 
The second problem is found in the words translated "you shall surely release." The Hebrew uses the word ("to leave," "to abandon"53), the same as in "you shall stop from leaving it to him"). What does this mean, "You shall stop from leaving it to him alone, you shall surely leave (it) with him!"? The LXX reads, "You shall work together with him."

The text probably uses a wordplay, "You shall stop from leaving it to him alone. Instead you should make sure that you help your enemy releasing (leaving) the donkey." Alden points out that the related Aramaic root šêzēb means "deliver." In the present context, the word therefore could mean "help." ${ }^{44} \mathrm{An}$ other way to solve that problem is to change the word עזר ("to help"), although there is no text-critical evidence (besides the translation of the LXX).

There are other passages in the OT, where the term also presents problems. In Neh 3:8 and 34, the translation of עזב seems to be "to fortify" or "to restore." ${ }^{, 5}$ It therefore seems best to think that עזב the main translation "to leave," "to abandon." The meaning of the passage can only be, "If the donkey of your enemy breaks down under his burden, do not leave the problem to your enemy alone, but help him to release the donkey from his burden." It, therefore, belongs to the category of animal protection laws.

The same is true for Deut 25:4, which we have already touched on, "You shall not muzzle an ox when it is threshing."

Many commentators argue that this verse is clearly one of the laws concerning animal protection. ${ }^{56}$ Oxen were used for ploughing the fields and for threshing the grain. They were thus instrumental both at the beginning and at the end of the whole process. Walton et al. therefore argue that, "[t]he injunction that the ox not be muzzled follows the humanitarian pattern of previous laws and allows the animal to eat a portion of the grain as its wage. $" 57$

Philo links this law in Deut 25:4 with the one in Deut 22:10: "You shall not plow with an ox and a donkey (harnessed) together." He explains that there are two reasons for this law: 1) The donkey is unclean, while the ox is clean, "and it is not becoming to bring together animals which are so utterly alienated"; and 2) They are unequal in their strength; God cares about the weaker one (the ass), and wishes to ensure that it is not oppressed and worn out. He then applies this to Israel (the clean animal) and the nations (the unclean animal). His moral

53 Cf. Gesenius, Wörterbuch, 943f.

54 Alden, “עזבע," 364.

55 Ibid.

56 E.g. Schrage, Korinther, 299-299; Schnabel, Korinther, 486.

57 Walton et al., IVP Bible Background Commentary, 199. 
is that Israel should not "injure any one of a different nation" just because they are of a different nationality. ${ }^{58}$

This law is one of the laws that forbid the mixing of different things together. There are two possible understandings of these prohibitions. Gane believes the reason is that everything mixed belonged to God. This can be seen in Deut 22:9, the verse directly preceding the command not to plough with a donkey and an ox together. ${ }^{59}$ If someone uses two different kinds of seed together in his vineyard, the fruit would belong to God. Hieke, on the other hand, sees this command as an imperative of practical experience, because the two animals would hinder each other when trying to work together, ${ }^{60}$ as already explained by Philo.

If understood from the perspective of the order of creation, this might not be an unresolvable contradiction. God created this world with a given order. Thus, whereas an ass is weak and considered unclean, an ox is strong and considered clean ${ }^{61}$ To accept this order of creation is to honour God. Only God himself can change this given order. Therefore, all mixtures belong to his sphere alone. This is clearer in Lev 19:19:

Keep my statutes: Do not let two (different) kinds of your cattle lay down together, do not sow your fields with two (different) kinds (of seed), and a garment with two (different) kinds of thread shall not come upon you.

God created everything according to its species. A mixing of the different kinds would therefore be abhorrent to him. ${ }^{62}$ It would mean that humans try to "play God," 63 it would be "ein unzulässiger Eingriff in die Schöpfungsordnung

58 Philo, De virt., 146. Interestingly, he does not apply it to the question of whether or not an Israelite should work together with or marry a heathen, which would be close to Paul's intention in applying this law in 2 Cor 6:14.

59 Gane, Leviticus, Numbers, 338; cf. also Milgrom, Leviticus, 1660.

60 Hieke, Leviticus, 737.

61 It must be made clear that these categories of clean and unclean or the laws forbidding the mixture or animals, fruit or material for clothing are not universally valid categories. They are examples which could be understood by the people of Israel and the surrounding nations. Their goal was to demonstrate the order of creation and to honour the God, who created everything.

62 Kiuchi argues that, "the reason for this prohibition has been explained by suggesting that mixed breeding represents the introduction of disorder into God's creation. However... it is more likely that the prohibition aims to inculcate the truth that mixtures belong to the holy realm" (Kiuchi, Leviticus, 355). As already argued, this need not necessarily be an either/or question, but can instead be seen as two aspects of the same idea.

63 It is strange that Gerstenberger believes that these laws "auf einen uralten Dämonenglauben zurückzugehen. Gegenstände und Wesen verschiedener Art dürfen 
Gottes." 64 The text therefore starts with the command, "Keep my statutes." Again, we can see that this has direct relevance to some of the major ethical questions that arise today. John Hartley is correct in his conclusion that, "this law seeks to prevent the blurring of the variety of species and kinds that God created; that is, it seeks to preserve the diversity in the created world."65

Another one of the orders of creation is the cycle of six days of work and one day of rest. Transgression of this law attracts the penalty of death (Exod 31:15), which makes it a very important instruction. In Exod 23:12 we learn that the beneficiaries of this law are not only human beings, but also animals:

For six days you shall do your work, but on the seventh day you shall cease to work, so that your ox and your donkey shall rest and the son of your maid and the stranger shall refresh themselves.

The reason for the instruction not to work on the seventh day is "that your ox and your donkey shall rest." Again, we find here an order of creation that encompasses the whole of the created world, humans and animals alike. This is also true of the Sabbath of complete rest in each seventh year. In Lev 25:4-7, we read:

\begin{abstract}
${ }^{4}$ And in the seventh year there shall be a Sabbath of complete rest for the land, a Sabbath for Yahweh. You shall not sow your field and not prune your vineyard. ${ }^{5}$ The aftergrowth of your harvest you shall not reap and you shall not cut of the grapes of your untrimmed vines. A Sabbath of complete rest shall it be for the land. The Sabbath of the land shall it be for you. ${ }^{6}$ As food for you, your servants, your maid, your labourer and your tenant, living with you, ${ }^{7}$ and for your cattle and for the animals in your land shall be all its product to eat.
\end{abstract}

The humans (you, your servants, your maid, your labourer and your tenant), the cattle and the wild animals shall benefit from this seventh year as well as the land itself. This clearly shows what Murray calls "the belief in a divinely willed order harmoniously linking heaven and earth."66

\title{
C CONCLUSION
}

nicht beliebig vermischt werden, weil sie jeweils eine gewisse Autonomie und unverletzliche Mächtigkeit besitzen. Durch Vermischung würde die Eigenart jedes Teils zerstört, würden die zugehörigen Dämonen oder Gottheiten beleidigt, verletzt, in ihrer Existenz bedroht" (Gerstenberger and Kaiser, Leviticus, 249). There is no hint of such an understanding, either in the text itself or in the related passages.

64 Hieke, Levitcus, 737; cf. also Wenham, Gordon J., The Book of Leviticus (NIVCOT 3; Grand Rapids: Eerdmans, 1981), 269.

65 John E. Hartley, Leviticus (WBC 4; Nashville: Word Books, 2000), 318.

66 Murray, Cosmic Covenant, xx. 
Wünch, "Does God Care about the Oxen," OTE 33/3 (2020): 538-555 553

We could continue and examine other texts relating to animals in the Old Testament, such as the narrative of Balaam and his donkey (Num 22:22-30), the parable of Nathan about the man and his sheep (2 Sam 12:1-6) or the various passages dealing with the relationship between a shepherd and his sheep (e.g. Pss 78:1-21; 23; Ezek 34:15-16; Isa 40:11). They all show the same concern for the animal world that we have already seen in the various law texts.

Instead, however, I would like to end with another quotation from Murray that perfectly condenses the main idea of this article. He says,

It is important to appreciate how much sense of responsibility for other creatures is expressed and commanded in the Torah... The theme of God's knowledge of and care for all creatures is strongly represented in the Bible. ${ }^{67}$

\section{BIBLIOGRAPHY}

Alden, Robert L. "עזב." Pages 364-365 in New International Dictionary of Old Testament Exegesis 4. Edited by Willem A. van Gemeren. Carlisle: Paternoster, 1997.

Brewer, D. Instone. "1 Corinthians 9.9-11: A Literal Interpretation of 'Do not Muzzle the Ox."” New Testament Studies 38/4 (1992): 554-565.

Carmichael, Calum M. "On Separating Life and Death: An Explanation of Some Biblical Laws." Harvard Theological Review 69/1-2 (1976): 1-7.

Christensen, Duane L. Deuteronomy 21:10-34:12. Word Biblical Commentary 6B. Nashville: Word Books, 2002.

Ciampa, Roy E. and Brian S. Rosner. The First Letter to the Corinthians. The Pillar New Testament Commentary. Grand Rapids: Eerdmans, 2010.

Craigie, Peter C. The Book of Deuteronomy. 3rd edition. The New International Commentary on the Old Testament 5. Grand Rapids: Eerdmans, 1981.

Durham, John I. Exodus. Word Biblical Commentary 3. Texas: Word Books, 1987.

Enns, Peter. Exodus. The NIV Application Commentary. Grand Rapids: Zondervan, 2000

Fretheim, Terence E. "רצה." Pages 1185-1186 in New International Dictionary of Old Testament Exegesis. Vol. 4. Edited by Willem A. van Gemeren. Carlisle: Paternoster, 1997.

Gane, Roy. Leviticus, Numbers: From Biblical Text... to Contemporary Life. The NIV Application Commentary. Grand Rapids: Zondervan, 2004.

Garrett, Duane A. A Commentary on Exodus. Kregel Exegetical Library. Grand Rapids: Kregel Academic, 2014.

Gerstenberger, Erhard S. and Otto Kaiser. Das dritte Buch Mose. Leviticus. 6 völlig neubearb. Aufl. Das Alte Testament Deutsch 6. Göttingen: Vandenhoeck \& Ruprecht, 1993.

Gesenius, Wilhelm. Hebräisches und Aramäisches Handwörterbuch über das Alte Testament. 18. Aufl. Heidelberg: Springer, 2013.

67 Ibid., 120. 
Gräßer, Erich. "Noch einmal: 'Kümmert sich Gott etwa um die Ochsen?'” Zeitschrift für die Neutestamentliche Wissenschaft 97/3-4 (2006): 275-279.

Hartley, John E. Leviticus. Word Biblical Commentary 4. Nashville: Word Books, 2000.

Hieke, Thomas. Levitikus. Zweiter Teilband 16-27. Herders Theologischer Kommentar zum Alten Testament 3/2. Freiburg im Breisgau: Herder, 2014.

Keener, Craig S. Kommentar zum Umfeld des Neuen Testaments. Historische, kulturelle und archäologische Hintergründe. 3 Bde. Neuhausen-Stuttgart: Hänssler, 1998.

Keil, Carl Friedrich and Franz Delitzsch. The Pentateuch. Translated from the German. Commentary on the Old Testament 1. 5th edition. Grand Rapids: William B. Eerdmans, 1978.

Kiuchi, Nobuyoshi. Leviticus. Apollos Old Testament Commentary 3. Downers Grove: InterVarsity Press, 2007.

Longman, Tremper and David E Garland. Genesis-Leviticus. The Expositor's Bible Commentary 1. Revised edition. Grand Rapids: Zondervan, 2005.

Longman, Tremper and David E Garland. Numbers-Ruth. The Expositor's Bible Commentary 2. Revised edition. Grand Rapids: Zondervan, 2012.

Milgrom, Jacob. Leviticus. A New Translation with Introduction and Commentary. The Anchor Bible 3A. London: Yale University Press, 2008.

Murray, Robert. The Cosmic Covenant: Biblical Themes of Justice, Peace and the Integrity of Creation. Heythrop Monographs 7. London: Sheed \& Ward, 1992.

Noth, Martin. Das zweite Buch Mose (Exodus). Das Alte Testament DeutschNeubearbeitungen 5. 8th edition. Göttingen: Vandenhoeck \& Ruprecht, 2011.

Otto, Eckart. Deuteronomium 12-34. Erster Teilband: 12,1-23,15. Herders Theologischer Kommentar zum Alten Testament 5/3. Freiburg: Herder, 2016.

Philo. On the virtues (De virtues). Early Jewish Writings. Cited 19.07.2018 Online: http://www.earlyjewishwritings.com/text/philo/book31.html.

Schnabel, Eckhard J. Der erste Brief des Paulus an die Korinther. 2., ber. und erg. Aufl. Historisch-theologische Auslegung, HTA. Witten: Brockhaus, 2010.

Schrage, Wolfgang. Der erste Brief an die Korinther $(1$ Kor 6,12-11,16). EvangelischKatholischer Kommentar zum Neuen Testament VII/2. Zürich, NeukirchenVluyn: Neukirchener, 1995.

Strack, Hermann L. and Paul Billerbeck. Kommentar zum Neuen Testament aus Talmud und Midrasch. Dritter Band: Die Briefe des Neuen Testaments und die Offenbarung Johannis. München: C. H. Beck, 1926.

Stuart, Douglas K. Exodus. The New American Commentary 2. Nashville: Broadman and Holman Publishers, 2006.

Thiselton, Anthony C. The First Epistle to the Corinthians: A Commentary on the Greek Text. The New International Greek Testament Commentary. Grand Rapids: Eerdmans, 2007.

Walton, John H., Victor Harold Matthews and Mark William Chavalas. The IVP Bible Background Commentary. Old Testament. 6th edition. Downers Grove: InterVarsity Press, 2004.

Wenham, Gordon J. The Book of Leviticus. The New International Commentary on the Old Testament 3. Grand Rapids: Eerdmans, 1981. 
Wünch, "Does God Care about the Oxen," OTE 33/3 (2020): 538-555 555

Wolff, Christian. Der erste Brief des Paulus an die Korinther. Theologischer Handkommentar zum Neuen Testament 7. Leipzig: Evangelische Verlagsanstalt, 2011.

Wolff, Christian. Der erste Brief des Paulus an die Korinther. Zweiter Teil: Auslegung der Kapitel 8-16. Theologischer Handkommentar zum Neuen Testament VII/2. Berlin: Evangelische Verlagsanstalt, 1982.

Zeller, Dieter and Heinrich August Wilhelm Meyer. Der erste Brief an die Korinther. Kritisch-exegetischer Kommentar über das Neue Testament 5. Göttingen: Vandenhoeck \& Ruprecht, 2011.

Prof. Dr. Hans-Georg Wünch, Im Dorfgarten 4, D-57610 Michelbach, Germany. Email: hans-georg.wuench@tsr.de. Affiliation: Theologisches Seminar Rheinland, Germany, and Department of Biblical and Ancient Studies, University of South Africa. ORCID: https://orcid.org/0000-0003-0752-4643. 